\title{
Skill Development and Training Requirements of the Aquaculture Sector in Andhra Pradesh, India: - A Need For Sustainable Economic Growth
}

\author{
Nandan MJ* \\ CSIR-National Geophysical Research Institute, Hyderabad, India
}

Submission: February 10, 2017; Published: February 20, 2017

*Corresponding author: Nandan MJ, CSIR-National Geophysical Research Institute, Uppal Road, Hyderabad - 500 007, Telangana, India,

Email:mjnandan@gmail.com

\section{Introduction}

Aquaculture is one of the world's fastest growing industries, with an average growth rate of over 8\% per year for the past ten years. India is the second-largest player in the global fisheries sector; producing around 90.4 lakh MT of fisherybased resources annually Ayyappan [1]. With an overall annual growth rate of about $4 \%$ during the 11th Five Year Plan period, the sector contributed about $1 \%$ to the National Gross Domestic Production (GDP) and 5.58\% to the agricultural GDP (201314 ) and also employs nearly 14 million people. The Indian aquaculture industry will face many challenges over the next few years to be economically, socially and environmentally sustainable. The industry will require highly educated, trained and experienced staff to address successfully these key issues and to meet further anticipated future growth. Andhra Pradesh ranks first in coastal aquaculture and fresh water aquaculture and ranks second in fresh water fish production and overall value of fish/prawn production in India. Andhra Pradesh contributes nearly 40 per cent of the total marine exports of the country. Inland resources comprise 102 reservoirs of which 7 are large, 26 are medium and 69 are small reservoirs. There are two lakes - Kolleru Lake, a freshwater lake and Pulicat lake - a brackish water lake. 74,000 perennial, seasonal and long seasonal tanks, fishponds and freshwater prawn ponds for aquaculture are also present in Andhra Pradesh. Brackish water resources comprise 0.78 lakh hectares for shrimp culture, a coastline of $974 \mathrm{kms}$ and 508 fishing villages.

Farmers in coastal Andhra Pradesh are fastly moving towards aquaculture from traditional agriculture and the land under fresh water and brackish water aquaculture has seen a fivefold increase to 82,000 hectares in the last three years. During this period, the industry grew from Rs 346 crore to Rs 561 crore. Further investments of over Rs 400 crore are expected to flow in from as many as 20 integrated units which are coming up in the state. The boom has very good reasons to back it up. Fish farming brings in more profits than agriculture. Growing two crops of paddy a year requires Rs 12,000 to Rs 15,000 per hectare in capital expenses, for which profits would range between Rs 5,000 and Rs 7,000. On the other hand, even traditional fish farming nets Rs 30,000 in profits, annually, on capital investments of Rs 50,000. Despite start-up expenses being higher, operational costs are half that of agriculture, as fish farming requires less labour.

Large companies, fishermen cooperatives, and finance companies are now queuing up for leases for land along and adjacent to the state's coastline, looking to cash in on about 17,000 hectares. Already, more than a fifth has been leased out. Considering the strength of aquaculture as one of the important sector for economic growth, the government of India has recently come up with a program "Blue Revolution" by consolidating all fisheries programs and activities. But the sustenance of this sector is highly dependent on the availability of skilled manpower.

Skill Development Needs for Sustainable Aquaculture in Andhra Pradesh

Skill development and training of personnel for Aquaculture industry in Andhra Pradesh is of the utmost importance for the growth and development of a sustainable Aquaculture industry. Indian Council of Agriculture Research (ICAR), the nodal agency for agricultural research in India, has eight fisheries research institutes of which three are mainly responsible for research into aquaculture. All these institutes are basically R\&D oriented and at present there is no organization exists working towards the skill development issues of aquaculture industry. Apart from fish production lot of associated industries are linked with the aquaculture industry and large demand exists for skilled manpower in these sectors. 
Skill development is critical not only for achieving faster, sustainable and inclusive growth but for providing decent employment opportunities to the growing labour force. India enjoys demographic dividend where more than $50 \%$ of its population is in the working age group of 15-59. This is sufficient to make India a skill capital of the world. However, skilling the large and growing young population is a challenge given that the education level of the labour force is very low, institutional capacity is inadequate, no labour market information system to update the skill levels through continuous up gradation of curriculums; lack of mobility; limited outreach and no industry linkage.

As per NSS latest Employment and Unemployment survey only about $10 \%$ of the labour force in the age group $15-59$ is vocationally trained ( $2 \%$ formally and $8 \%$ informally). Further the general education level of more than $50 \%$ of India's labour force in the age group 15-59 remains extremely low- about 29\% are not even literate and another $24 \%$ are having education up to primary level. Only about $17 \%$ have higher level of education including higher secondary. The available data indicates that about 54\%of the persons who are unemployed are either illiterate or just about primary education. The number of persons above diploma level is just about $9.52 \%$. It seems lot of potential exists for skill development in aquaculture sector.

\section{Skill Development programs for Sustainable Aquaculture}

Considering the huge potential for skill development in aquaculture sector the following important programs are suggested various categories of people:

\section{Vocational training for school dropouts}

In India national dropout rate at the primary level is 4.34 per cent in 2014-15 and it is even higher at the secondary level, at 17.86 per cent. Poverty, availability and accessibility are the important reasons for the children drop out of schools. A vocational training program which includes practical skills and knowledge to pursue a career in aquaculture/fisheries/fishery industries is most suitable primarly for high school dropouts.
A study and practical training over 2-4 months and some work experience will provide an employment opportunity as apprentice in the aquaculture sector.

\section{Aquaculture apprentices}

The modern apprenticeship programme provides practical training and skills development for unemployed rural youth working in the aquaculture industry, from new entrants to experienced staff. Students on the programme spend most of their time learning 'on-the-job' at their employers' aquaculture sites, and additional training is provided where ever required. The programme may be offered at two levels:

Level 1: is for workers new to the aquaculture industry and helps them to develop the basic skills and knowledge needed to work effectively within the industry.

Level 2: is aimed at more experienced workers, senior site staff and trainee managers who already have a good understanding of the aquaculture industry

\section{For fish farmers}

Apart from the unemployed youth and school dropouts, many of the farmers are engaged in aquaculture sector that requires different levels of training in the areas. These training programs are mainly designed to provide right skills and knowledge to be a competent fish farmer. Depending upon the educational level and operations, skill development programs of different durations ranging from 3-5 weeks may be designed.

\section{Summary}

Government of India is operating a high level National Skill Development Mission and a great potential exists with aquaculture industry which requires huge manpower at different levels. If appropriate skill development programs are implemented in this sector, it will be a great boon for the aquaculture industry not only in Andhra Pradesh for other parts of the country.

\section{References}

1. Ayyappan, S (2014) National Aquaculture Sector Overview, India. FAO Fisheries and Aquaculture Department, Rome.

\section{Your next submission with Juniper Publishers will reach you the below assets}

- Quality Editorial service

- Swift Peer Review

- Reprints availability

- E-prints Service

- Manuscript Podcast for convenient understanding

- Global attainment for your research

- Manuscript accessibility in different formats ( Pdf, E-pub, Full Text, Audio)

- Unceasing customer service

\section{Track the below URL for one-step submission}

https://juniperpublishers.com/online-submission.php 